Editors

G.M. Berlyne, Brooklyn, N.Y.

S. Giovannetti, Pisa

Editorial Board

A. Adler, Brooklyn, N.Y.

G. Andres, Buffalo, N.Y.

V.E. Andreucci, Napoli

P.-O. Attman, Göteborg

M. Avram, Brooklyn, N.Y.

A. Avramides, Thessaloniki

R.R. Bailey, Christchurch

D.S. Baldwin, New York, N.Y.

P. Bálint, Budapest

G. Barsotti, Pisa

U.S. Barzel, Bronx, N.Y.

G. Becker, Parkville

J. Ben-Ari, Haifa

V. Beroniade, Montreal, P.Q.

O.S. Better, Haifa

M.M. Beyer, Brooklyn, N.Y

Ch.R. Blagg, Seattle, Wash.

M.D. Blaufox, New York, N.Y.

V. Bonomini, Bologna

D. Brancaccio, Milano

N. Brautbar, Los Angeles, Calif.

O.-E. Brodde, Essen

B. Broumand, Teheran

U. Buoncristiani, Perugia

E. Burke, Atlanta, Ga.

F. Cantarovich, Buenos Aires

H. Carroll, Brooklyn, N.Y.

W.R. Cattell, London

C. Chaimovitz, Beersheva

J. Chanard, Reims

J. Churg, New York, N.Y.

F.L. Coe, Chicago, Ill.

B.D. Cohen, Bronx, N.Y.

G. D'Amico, Milano

N. Di Paolo, Siena

V.A. Di Scala, Mineola, N.Y.

P.B. Disler, Palmerston North

E.J. Dorhout-Mees, Utrecht

T. Drüeke, Paris

R. Dzúrik, Bratislava

B.T. Emmerson, Brisbane, Queensl.

G. Falcone, Pisa

R.N. Fine, Los Angeles, Calif.

E.A. Friedman, Brooklyn, N.Y.

P. Fröhling, Potsdam

J.-L. Funck-Brentano, Paris

P. Fürst, Stuttgart

M.H. Gault, St. John's, Newfoundland

M. Ghavamian, Teheran
C. Giordano, Napoli

A. Goldberg, Baltimore, Md.

I. Greifer, Bronx, N.Y.

N. Gretz, Mannheim

B. Griffel, Kfar Saba

G.F. Guarnieri, Trieste

R. Gusmano, Genova

R. Habib, Paris

M. Hatano, Tokyo

A.G. Hocken, Oamaru

W.H. Hörl, Freiburg i.Br.

S. Indraprasit, Bangkok

J.D. Jones, Rochester, Minn.

M. Kashgarian, New Haven, Conn.

D.N.S. Kerr, London

C.M. Kjellstrand, Minneapolis, Minn.

C.R. Kleeman, Los Angeles, Calif.

H. Klinkmann, Rostock

K.M. Koch, Hannover

H. Köhler, Mainz

F. Kokot, Katowice

K. Kopp, München

J.D. Kopple, Torrance, Calif.

H. Kramer, Bonn

F. Krueck, Bonn

K. Kühn, Hannover

C.M. Kunin, Columbus, Ohio

E. Lieberman, Los Angeles, Calif.

F. Llach, Oklahoma City, Okla.

G. Lubec, Vienna

R.G. Luke, Birmingham, Ala.

M.L. Maayan, Brooklyn, N.Y.

K. Maeda, Nagoya

Q. Maggiore, Reggio di Calabria

J.F. Maher, Bethesda, Md.

N.P. Mallick, Manchester

H.H. Malluche, Lexington, Ky.

G. Maschio, Verona

S.G. Massry, Los Angeles, Calif.

M.H. Maxwell, Los Angeles, Calif.

P. Metaxas, Thessalonica

P. Michielsen, Leuven

L. Migone, Parma

L. Minetti, Milano

L.J. Morel-Maroger Striker, Bethesda, Md.

P.A.F. Morrin, Kingston, Ont.

B. Nikakhtar, Santa Monica, Calif.

K.D. Nolph, Columbia, Mo.

B.E.C. Nordin, Adelaide
I. Nussenzveig, São Paulo

K. Ohta, Nagoya

D.G. Oreopoulos, Toronto, Ont.

T. Orlowski, Warsaw

F. Panicucci, Pisa

V. Parsons, London

A. Pasternack, Tampere

M. Peacock, Leeds

D.K. Peters, London

C. Pirani, Glen Rock, N.J.

V.E. Pollak, Cincinnati, Ohio

C. Ponticelli, Milano

J.G. Porush, Brooklyn, N.Y.

H.G. Preuss, Washington, D.C.

J.P. Revillard, Lyon

R.E. Rieselbach, Milwaukee, Wisc.

E. Ritz, Heidelberg

J.S. Robson, Edinburgh

A. Salvetti, Pisa

F.P. Schena, Bari

R. Schmicker, Rostock

M.M. Schwartz, Chicago, Ill.

R. Shainkin-Kestenbaum, Beersheva

S. Shaldon, Montpellier

A.H. Shapiro, London, Ont.

T. Sherwood, Cambridge

N. Siegel, New Haven, Conn.

S. Stefoni, Bologna

W.K. Stewart, Dundee

M. Strauch, Mannheim

J. Strauss, Miami, Fla.

W.N. Suki, Houston, Tex.

J. Takeuchi, Tokyo

I. Tareyeva, Moscow

A. Tejani, Brooklyn, N.Y.

N.M. Thomson, Melbourne

A. Tizianello, Genova

A. Vangelista, Bologna

V. Vertes, Cleveland, Ohio

R. Waldherr, Heidelberg

E.N. Wardle, Abha

L.G. Wesson, Philadelphia, Pa.

K. zum Winkel, Heidelberg

H.A. Yatzidis, Athens

E.T. Zawada, Jr., Sioux Falls, S. Dak.

R. van Zyl-Smit, Cape

P. Zucchelli, Bologna 


Universitüt3-
Bintichek
Munchen

S. Karger $\cdot$ Medical and Scientific Publishers Basel · München · Paris · London · New York · New Delhi · Bangkok · Singapore · Tokyo · Sydney

\section{Drug Dosage}

The authors and the publisher have exerted every effort to ensure that drug selection and dosage set forth in this text are in accord with current recommendations and practice at the time of publication. However, in view of ongoing research, changes in government regulations, and the constant flow of information relating to drug therapy and drug reactions, the reader is urged to check the package insert for each drug for any change in indications and dosage and for added warnings and precautions. This is particularly important when the recommended agent is a new and/or infrequently employed drug.

\section{All rights reserved.}

No part of this publication may be translated into other languages, reproduced or utilized in any form or by any means, electronic or mechanical, including photocopying, recording, microcopying, or by any information storage and retrieval system, without permission in writing from the publisher or, in the case of photocopying, direct payment of a specified fee to the Copyright Clearance Center (see 'Information for Readers and Subscribers').

(c) Copyright 1989 by S. Karger AG, P.O. Box, CH-4009 Basel (Switzerland) Printed in Switzerland by Graphische Betriebe Coop Schweiz, Basel 


\section{No. 1}

\section{Editorial}

Dialysis in the Third World

Berlyne, G.M.

\section{Original Papers}

Brainstem Auditory Evoked Responses in Chronic Renal Failure and the Effect of Hemodialysis

Gafter, U.; Shvili, Y.; Levi, J.; Talmi, Y.; Zohar, Y. . . .

1-Deamino-8-D-Arginine Vasopressin Lowers Protein C Activity in Uremics

Aunsholt, N.A.; Schmidt, E.B.; Stoffersen, E. . . . . . . .

Three-Dimensional Ultrastructural Changes of Acellular Glomerular Basement Membrane in Various Types of Human Glomerulonephritis

Nishimura, S.; Makino, H.; Ota, Z. . . . . . . . . . . . .

Steady-State Plasma Levels and Pharmacokinetics of Guanfacine in Patients with Renal Insufficiency

Carchman, S.H.; Sica, D.A.; Davis, J.; Crowe, J.T., Jr.; Wasserman, A.J.; Proctor, J.D.; Wright, G.J. . . . . . .

Successful Peritoneal Dialysis Using $0.9 \%$ Sodium Chloride with Modified M/6 Sodium Lactate Solution and Recycled Catheters

Onwubalili, J.K. . . . . . . . . . . . . .

Perimembranous-Type Renal Amyloidosis: A Peculiar Form of AL Amyloidosis

Shiiki, H.; Shimokama, T.; Yoshikawa, Y.; Onoyama, K.; Morimatsu, M.; Watanabe, T. . . . . . . . . . . .

Urinary Total Protein Estimation - Fact or Fiction? Chambers, R.E.; Bullock, D.G.; Whicher, J.T. . . . . . . .

Collagen-Binding Affinity of Beta-2-Microglobulin, a Preprotein of Hemodialysis-Associated Amyloidosis

Homma, N.; Gejyo, F.; Isemura, M.; Arakawa, M. . . . .

Cellular Immunity Analysis Using Monoclonal Antibodies in Human Glomerulonephritis

Arrizabalaga, P.; Mirapeix, E.; Darnell, A.; Torras, A.; Revert, L. . . . . . . . . . . . . . .

Thrombin Inhibits the Synthesis of Prostanoids by Isolated Glomeruli and Peritoneal Macrophages in Rats

Podjarny, E.; Rathaus, M.; Pomeranz, A.; Shapira, J.; Bernheim, J. . . . . . . . . . . . . . . . .

Vitamin D, Desferrioxamine and Aluminum-Induced Bone Disease in Uremic Rats

Verbeelen, D.; Smeyers-Verbeke, J.; van Hooff, I.; de Roy, G.

IgA Nephropathy - Groote Schuur Hospital Experience Swanepoel, C.R.; Madaus, S.; Cassidy, M.J.D.; TempleCamp, C.; Van Diggelen, N.T.; Pascoe, M.D.; van ZylSmit, R. . . . . . . . . . . . . . .

Influence of Type of Immunosuppressive Therapy on Secretion of Somatotropin and Function of the Pituitary-Adrenal and Pituitary-Gonadal Axis in Patients with a Kidney Transplant

Nieszporek, T.; Grzeszcznak, W.; Kokot, F.; ŻukowskaSzszechowska, E.; Kuśmierski, S.; Szkodny, A. . . . . . .

\section{Case Reports}

Nephronophthisis-Cystic Renal Medulla Complex: Diagnosis by Computerized Tomography

McGregor, A.R.; Bailey, R.R. . . . . . . . . . . .

Subcutaneous Amyloid-Tumor of Beta-2-Microglobulin Origin in a Long-Term Hemodialysis Patient

Floege, J.; Brandis, A.; Nonnast-Daniel, B.; WesthoffBleck, M.; Tiedow, G.; Linke, R.P.; Koch, K.M. . . . . .

Rhabdomyolysis and Acute Renal Failure after Terbutaline Overdose

Blake, P.G.; Ryan, F. . . . . . . . . . . . . .

\section{Short Communication}

The Hypocalcemic Effect of Inorganic Sulfate Infusions Cole, D.E.C.; McPhee, M.D.; Crocker, J.F.S.

\section{Letters to the Editor}

Renal Histology for the Diagnosis of Primary Hyperoxaluria in Patients with End-Stage Renal Disease Murty, M.L.N.; Garg, I.; Date, A.; Jacob, C.K.; Kirubakaran, M.G.; Shastry, J.C.M. . . . . . . . . . . . . .

Acetoacetate Does Not Prevent Maleate-Induced Proteinuria in Rats

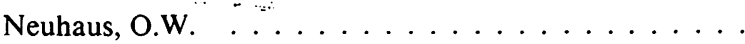

Acute Tubular Necrosis following Co-Trimoxazole Therapy

Rudra, T.; Webb, D.B.; Evans, A.G. . . . . . . . . . .

Modification of Serum Beta-2-Microglobulin in Chronic Hemodialysis Patients

Ozasa, H.; Suzuki, T.; Ota, K. . . . . . . . . . . . . . .

Dialysis after Bilateral Nephrectomy. A Case Report Candela, A.M.; Liaño, F.; Jiménez, M.; Ortuño, J. . . . .

Temperature Effects on Renal Membrane Ionic Permeability Schell, R.E. . . . . . . . . . . . . . .

Campylobacter pylori in Uremic Dialyzed Patients Conz, P.; Chiaramonte, S.; Ronco, C.; Feriani, M.; La Greca, G. . . . . . . . . . . . . . . . . . . .

Increased Ultrafiltration after Erythropoietin-Induced Correction of Renal Anemia in Patients on Continuous Ambulatory Peritoneal Dialysis Steinhauer, H.B.; Lubrich-Birkner, I.; Dreyling, K.W.; Hörl, W.H.; Schollmeyer, P. . . . . . . . . . . . . 


\section{No. 2}

\section{Original Papers}

Disappearance of Aluminic Bone Disease in a Long Term Asymptomatic Dialysis Population Restricting $\mathrm{Al}(\mathrm{OH})_{3}$ Intake: Emergence of an Idiopathic Adynamic Bone Disease Not Related to Aluminum

Morinière, P.; Cohen-Solal, M.; Belbrik, S.; Boudailliez, B.; Marie, A.; Westeel, P.F.; Renaud, H.; Fievet, P.; Lalau, J.D.; Sebert, J.L.; Fournier, A. . . . . . . . . . . . . .

Favorable Effects of Fish Oil Concentrate on Risk Factors for Thrombosis in Renal Allograft Recipients Urakaze, M.; Hamazaki, T.; Kashiwabara, H.; Omori, K.; Fischer, S.; Yano, S.; Kumagai, A. . . . . . . . . . . . 102

Beta-2-Microglobulin in Hemodiafiltered Children: LongTerm Efficiency Follow-Up

Fischbach, M; Hamel, G.; Koehl, C.; Geisert, J. . . . . 110

Urinary Neopterin as a New Biochemical Marker for the Monitoring of Disease Activity and Prognosis in Membranous Nephropathy Associated with Hepatitis B Surface Antigenemia

Lin, C.-Y.

ffects of Dialysis and Transplantation on Red Cell Na Pump Function in Renal Failure

Fervenza, F.C.; Hendry, B.M.; Ellory, J.C. . . . . . . . . 121

Effects of a Low-Phosphorus, Low-Nitrogen Diet Supplemented with Essential Amino Acids and Ketoanalogues on Serum Beta-Endorphin in Chronic Renal Failure Ciardella, F.; Cupisti, A.; Catapano, G.; Guidi, A.; Pasquinucci, A.; Morelli, E.; Barsotti, G. . . . . . . . . . . . 129

Effect of a Simultaneous Potassium and Carbohydrate Load on Extrarenal K Homeostasis in End-Stage Renal Failure

Alvo, M.; Krsulovic, P.; Fernández, V.; Espinoza, A.M.; Escobar, M.; Marusic, E.T. . . . . . . . . . . . . . 133

Furosemide Accelerates Gentamicin Accumulation in Cultured Renal Cells (LLC-PK1 Cells)

Nakahama, H.; Fukuhara, Y.; Orita, Y.; Yamauchi, A.; Takama, T.; Kamada, T. . . . . . . . . . . . . 138

Changes in Intracranial Pressure during Haemofiltration in Oliguric Patients with Grade IV Hepatic Encephalopathy Davenport, A.; Will, E.J.; Davison, A.M.; Swindells, S.; Cohen, A.T.; Miloszewski, K.J.A.; Losowsky, M.S. . . . . 142

Mitogenic Activity on Human Arterial Smooth Muscle Cells Is Increased in the Plasma of Patients Undergoing Hemodialysis with Cuprophane Membranes

Hemmendinger, S.; Neumann, M.-R.; Beretz, A.; KleinSoyer, C.; Cazenave, J.-P.; Rich, A.; Schohn, D.; Jahn, H. 147

Kidneys of Chronic Alcoholic Rats Are More Vulnerable to Ischemic Insult

Ishigami, M.; Ohnishi, S.T.; Chan, R.; Shimada, Y.; Yabu-

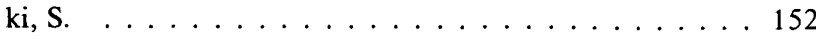

\section{Case Report}

Acquired Cystic Disease of the Kidneys and Renal Cell Carcinoma in Chronic Renal Insufficiency without Dialysis Treatment Chung-Park, M.; Parveen, T.; Lam, M. . . . . . . . . . .

\section{Letters to the Editor}

Serum Angiotensin-Converting Enzyme as a Marker of Dialyzer Membrane Biocompatibility?

Krämer, B.K.; Ulshöfer, T.; Ress, K.M.; Müller, G.A.; Risler, T. . . . . . . . . . . . . . . . 162

Variant of Bartter's Syndrome with a Distal Tubular Rather than Loop of Henle Defect

Koomans, H.A.; Hené, R.J.; Dorhout Mees, E.J.; Boer, W.H. . . . . . . . . . . . . . . . . . 164

Congenital Nephrotic Syndrome of the Finnish Type Bucciarelli, E.; Sidoni, A.; Alberti, P.F.; Lorusso, L.; Losito, A. . . . . . . . . . . . . . . . . . 166

Bone End Sclerosis Noël, C.; Leclet, H.; Dhondt, J.-L. . . . . . . . . . . . 168

Kaposi's Sarcoma in a Renal Allograft Recipient under Ciclosporin A

Riegler, P.; Corradini, R.; Huber, W.; Wallnöfer, W.; Egarter, E.; Königsrainer, A.; Spielberger, M.; Hintner, H.; Margreiter, R. . . . . . . . . . . . . . 171

Erythropoietin Does Not Induce Vasoconstriction Directly in Human Subcutaneous Resistance Arterioles Bund, S.J.; Heagerty, A.; Edmunds, M.; Walls, J. . . . . . 173

Continuous Ambulatory Peritoneal Dialysis, Protective against Developing Dialysis-Associated Amyloid? Tielemans, C.; Dratwa, M.; Bergmann, P.; Goldman, M.; Flamion, B.; Collart, F.; Wens, R. . . . . . . . . . . . 174

Ventricular Tachyarrhythmia Treated by Parathyroidectomy in a Chronically Hemodialyzed Patient

Kimura, K.; Tabei, K.; Asano, Y.; Hosoda, S. . . . . . . . 176

Spontaneous Bacterial Peritonitis and Renal Allograft Recipients

Pascual, J.; Sureda, A.; Boixeda, D.; Liaño, F.; Ortuño, J. 178

Salmonella bonariensis Salmonellosis, Rhabdomyolysis, and Acute Renal Failure

Lagarde, C.; Peyronnet, P.; Denis, F.; Benzakour, M.; Leroux-Robert, C. . . . . . . . . . . . . . 179

Book Review . . . . . . . . . . . . . . . . 180

Announcement ............... 180 
No. 3

\section{Original Papers}

Effects of Chronic and Acute Protein Administration on Renal Function in Patients with Chronic Renal Insufficiency Bilo, H.J.G.; Schaap, G.H.; Blaak, E.; Gans, R.O.B.; Oe, P.L.; Donker, A.J.M. . . . . . . . . . . . . . 181

Hemodialysis-Related Induction of Beta-2-Microglobulin and Interleukin-1 Synthesis and Release by Mononuclear Phagocytes

Knudsen, P.J.; Leon, J.; Ng, A.-K.; Shaldon, S.; Floege, J.; Koch, K.M. . . . . . . . . . . . . . .

Effect of Intravenous 1-Alpha-Hydroxyvitamin $\mathrm{D}_{3}$ on Secondary Hyperparathyroidism in Chronic Uremic Patients on Maintenance Hemodialysis

Brandi, L.; Daugaard, H.; Tvedegaard, E.; Storm, T.; Olgaard, K. . . . . . . . . . . . . . . . . . . . . . . 194

Cardiac Arrhythmias in Hemodialysis Patients. A Study of Incidence and Contributory Factors

Kimura, K.; Tabei, K.; Asano, Y.; Hosoda, S. . . . . . . . 201

Effect of Hemodialysis on Serum Concentrations of HPLCAnalyzed Accumulating Solutes in Uremia Schoots, A.C.; Peeters, J.A.G.; Gerlag, P.G.G. . . . . . . 208

Renal Effects of Trimethoprim in Ciclosporin- and Azathioprine-Treated Kidney-Allografted Patients Berg, K.J.; Gjellestad, A.; Nordby, G.; Rootwelt, K.; Djøseland, O.; Fauchald, P.; Mehl, A.; Narverud, J.; Talseth, T. 218

Tubular Handling of Pepsinogen A and C in Man: Evidence for Two Distinct Tubular Reabsorption Mechanisms for Low Molecular Weight Proteins in Man ten Kate, R.W.; Pals, G.; Donker, A.J.M.; Pronk, J.C.; Meuwissen, S.G.M. . . . . . . . . . . . . . . . . 223

Serotonin Metabolism in Patients with Decreased Renal Function

Šebeková, K.; Raučinová, M.; Dzúrik, R.

Experimental Uraemia with Associated Plasma Amino Acid Abnormalities but without Retarded Food Intake and Weight Gain

Haines, D.J.; Swan, C.H.J.; Green, J.R.B.; Woodley, J.F. 233

Renal Effects of Indomethacin in Patients with Systemic Lupus erythematosus ter Borg, E.J.; de Jong, P.E.; Meijer, S.; Kallenberg, C.G.M. 238

Progression of Renal Failure in Analgesic-Associated Nephropathy

Schwarz, A.; Kunzendorf, U.; Keller, F.; Offermann, G. . 244

Moderately Proteinuric IgA Nephropathy: Prognostic Prediction of Individual Clinical Courses and Steroid Therapy in Progressive Cases

Kobayashi, Y.; Hiki, Y.; Fujii, K.; Kurokawa, A.; Tateno, S. 250

Protein Components of Amyloid-Like Kidney Stones of Chronic Hemodialysis Patients

Ozasa, H.; Suzuki, T.; Takahashi, K.; Ota, K. . . . . . . . 257

Myoglobinuria Exacerbates Ischemic Renal Damage in the Dog Mandal, A.K.; Davis, J.B., Jr.; Bell, R.D.; Miller, J.M. . . 261

Effect of Prednisone on Nephrotic Peripheral Blood Mononuclear Cell Mediated Increase in ${ }^{35}$ Sulfate Uptake in Rat Glomerular Basement Membrane

Garin, E.H.

\section{Case Report}

Propoxyphene-Induced Hypoglycemia in a Patient with Chronic Renal Failure

Almirall, J.; Montoliu, J.; Torras, A.; Revert, L. . . . . . 273

\section{Letters to the Editor}

Deferoxamine Does Not Increase the Risk for Bacteremia in Hemodialysis Patients

Tielemans, C.; Boelaert, J.; Vergauwe, P.; van Roost, G.; Segaert, M.; van Frachen, B.; Lenclud, C. . . . . . . . . . 276

Detection of DNA Polymerase-Alpha-Positive Cells in the Glomeruli from Patients with IgA Nephropathy

Eguchi, K.; Yagame, M.; Sakai, H.; Shirato, I.; Funabiki, K.; Tomino, Y. . . . . . . . . . . . . . . . 278

Renal Excretion of Phenols in Patients with Chronic Renal Insufficiency

Schück, O.; Vidláková, M.; Erben, J. . . . . . . . . . . . 279

Effect of Deferoxamine Mesylate on the Growth of Mucorales

Niimi, O.; Kokan, A.; Kashiwagi, N. . . . . . . . . . 28

Ciclosporin-Induced Partial and Transient Improvement of Nephrotic Syndrome in Recurrent Focal Segmental Glomerulosclerosis

Morales, J.M.; Andres, A.; Prieto, C.; Praga, M.; Gutierrez

Millet, V.; Rodicio, J.L. . . . . . . . . . . . . . . 283

IgA Nephropathy Complicated by Ulcerative Colitis Iida, H.; Asaka, M.; Izumino, K.; Takata, M.; Sasayama, S.;

Tanaka, M. . . . . . . . . . . . . . . . 285

The Neopterin/Creatinine Ratio Cannot Be Used to Diagnose Rejection Episodes in Renal Transplant Recipients Bäckman, L.; Ringdén, O. . . . . . . . . . . . . . . 287

Rectal Stenosis Associated with Fungal Peritonitis: A Complication of Continuous Ambulatory Peritoneal Dialysis Uchida, M.; Sakemi, T.; Nagano, Y.; Mizuguchi, M. . . .

Increased Plasma Levels of Human Atrial Natriuretic Factor in Patients Treated with Acetate of Bicarbonate Hemodialysis Manno, C.; Stella, M.; Fornarelli, G.; Cervellati, M.; Manno, M.; Schena, F.P. . . . . . . . . . . . . . . . . . 290

Interaction between Ciclosporin $\mathrm{A}$ and Sintrom Campistol, J.M.; Maragall, D.; Andreu, J. . . . . . . . . . 291

Announcement $\ldots \ldots \ldots \ldots \ldots \ldots$ 


\section{No. 4}

\section{Distinguished Scientists Lecture Series}

Humoral Abnormalities in X-Linked Hypophosphatemic Mice

Meyer, R.A., Jr. . . . . . . . . . . . .

\section{Original Papers}

Use of Permcath (Quinton) Catheter in Uraemic Patients in Whom the Creation of Conventional Vascular Access for Haemodialysis Is Difficult

Pourchez, T.; Morinière, P.; Fournier, A.; Pietri, J. . . . . 297

Improvement of Histological and Immunological Change in Steroid and Immunosuppressive Drug-Resistant Lupus nephritis by High-Dose Intravenous Gamma Globulin

Lin, C.-Y.; Hsu, H.-C.; Chiang, H. . . . . . . . . . . . 303

Ultrastructural Distribution of von Willebrand Factor in $\mathrm{Hu}-$ man Glomerular Diseases

Ono, T.; Kanatsu, K.; Doi, T.; Sekita, K.-J.; Onoe, C.; Nagai, H.; Muso, E.; Yoshida, H.; Tamura, T.; Kawai, C. 311

Hyponatremia in Patients with the Acquired Immunodeficiency Syndrome

Agarwal, A.; Soni, A.; Ciechanowsky, M.; Chander, P.; Treser, G. . . . . . . . . . . . . . . . 317

A Prospective Study on a Rapid Method for Diagnosing Cytomegalovirus Infections in Immunosuppressed Patients Aguado, S.; Gómez, E.; Rodríguez, A.; Martínez, A.; Oña, M.; Alvarez-Grande, J. . . . . . . . . . . . . . . . 322

Lipid Abnormalities and Peroxidation of Erythrocytes in Nephrotic Syndrome Clemens, M.R.; Bursa-Zanetti, Z. . . . . . . . . . . 325

Sequence of Glomerular Changes in Experimental Endotoxemia: A Possible Model of Hemolytic Uremic Syndrome Bertani, T.; Abbate, M.; Zoja, C.; Corna, D.; Remuzzi, G. 330

Biosynthesis of Complement $\mathrm{C} 4$ Messenger RNA in Normal Human Kidney

Feucht, H.E.; Zwirner, J.; Bevec, D.; Lang, M.; Felber, E.; Riethmüller, G.; Weiss, E.H. . . . . . . . . . . . 338

Immunohistochemical Study of a Tubular Basement Membrane Antigen in Normal Human Urinary Sediment by a Monoclonal Antibody

Orfila, C.; Rakotoarivony, J.; Serre, G.; Rahobisoa, N.; Suc, J.-M. . . . . . . . . . . . . . . . 343

Hyperuricemia and Renal Handling of Urate in Primary Hyperparathyroidism

Pepersack, T.; Jabbour, N.; Fuss, M.; Karmali, R.; Van Geertruyden, J.; Corvilain, J. . . . . . . . . . . . . . 349

Cardiac Output, Renal Blood Flow and Hepatic Blood Flow in Rats with Glycerol-Induced Acute Renal Failure Kishimoto, T.; Sakamoto, W.; Nakatani, T.; Ito, T.; Iwai, K.; Kim, T.; Abe, Y. . . . . . . . . . . . . . . 353

Characteristics of Rat Kidney Dopamine Receptors and the Effects of Renal Denervation and Dopamine Infusion of These Receptors Katayama, E.; Ogura, T.; Ota, Z. . . . . . . . . . . 358

The Acute Effect of Passive Heymann Nephritis on Renal Blood Flow and Glomerular Filtration Rate in Rats Sekse, I.; Iversen, B.M.; Matre, R.; Ofstad, J. . . . . . . . 364

\section{Case Report}

Multiple Myeloma and AL Amyloidosis in a Renal Transplant Recipient

Aparicio, M.; de Precigout, V.; Reiffers, J.; Deminière, C.; Morel, D.; Merville, P.; Bouchet, J.L.; Potaux, L. . . . . . 373

\section{Letters to the Editor}

Urinary Elastase: The Contribution of the Lower Urinary Tract

Cumming, J.A.; Cumming, A.D.; Dawes, J. . . . . . . . . 376

Acute Renal Failure following Massive Mannitol Infusion Rello, J.; Triginer, C.; Sánchez, J.M.; Net, A. . . . . . . 377

Red Cell Distribution Width: A Method That Improves Detection of Iron Deficiency in Chronic Hemodialysis Patients Díaz-Tejeiro, R.; Maduell, F.; Diez, J.; Esparza, N.; Errasti, P.; Purroy, A. . . . . . . . . . . . . . . . 379

Glomerular Deposition of Coagulation Factors VII, VIII, and IX in IgA Nephropathy: Possible Coagulation System Involvement in IgA Nephropathy Matsubara, M.; Akiu, N.; Ootaka, T.; Saito, T.; Yoshinaga, K. . . . . . . . . . . . . . 381

Plasma Zinc Decreases in Hemodialysis Patients Treated with Calcium Carbonate as the Phosphate Binder Gilli, P.; Docci, D.; Baldrati, L.; Turci, F. . . . . . . . . . 384

Acute Effect of Dipyridamole on Urinary Prostaglandin Excretion

Rogov, V.A.; Kutyrina, I.M.; Tareyeva, I.E. . . . . . . . 386

Vitamin E in Plasma of Patients with Chronic Renal Insufficiency

Porrini, M.; Simonetti, P.; Testolin, G.; Gentile, M.G.; Manna, G.M.; Fellin, G.; D’Amico, G. . . . . . . . . . . 387

Continuous Ambulatory Peritoneal Dialysis Does Not Prevent the Development of Dialysis-Associated Amyloidosis Miguel Alonso, J.L.; Cruz, A.; López Revuelta, K.; Caparrós, G.; Gonzáles, T.; Muñoz, J.; Martínez, M.E.; Selgas, R. 389

Evidence of Some Nonglomerular Bleeding in IgA Nephropathy

Docci, D.; Baldrati, L.; Turci, F.; Gilli, P. . . . . . . . . . 391

Beta-2-Microglobulin Excretion in Neonates Treated with Gentamicin

Arellano, F.

Response

Assadi, F.K. . . . . . . . . . . . . . . 393

Book Review . . . . . . . . . . . . . . . . . . 394

Announcement . . . . . . . . . . . . . . . 394

Author Index . . . . . . . . . . . . . . . . . . . . . . . . . . . . . . . . . . . . . . . . . . . . . .

Subject Index . . . . . . . . . . . . . . . 397 


\title{
Biosynthesis of Complement C4 Messenger RNA in Normal Human Kidney
}

\author{
H.E. Feucht ${ }^{\mathrm{a}, \mathrm{b}}$, J. Zwirner ${ }^{\mathrm{b}}$, D. Bevec ${ }^{\mathrm{b}}$, Margot Lang $^{\mathrm{b}}$, E. Felber $^{\mathrm{b}}$, G. Riethmüller $^{\mathrm{b}}$, Elisabeth H. Weiss ${ }^{\mathrm{b}}$ \\ ${ }^{a}$ Medizinische Klinik Innenstadt und ${ }^{b}$ Institut für Immunologie, Universität München, BRD
}

\section{Key Words. Complement C4 · Messenger RNA}

\begin{abstract}
Complementary DNA (cDNA) probes were used to investigate the extrahepatic production of the major histocompatibility complex (MHC)-linked complement components $\mathrm{C} 4$, factor $\mathrm{B}$ and $\mathrm{C} 2$ in various normal human tissues. The presence of the corresponding messenger RNA (mRNA) was tested by Northern blot analysis. Complement C4 mRNA was found in liver, and with high intensity also in normal kidneys. In contrast, no C 2 mRNA and only very low amounts of factor B mRNA could be detected in the kidney. Slot blot hybridization was performed to quantitate the amount of C4 mRNA, and the intensity of C4 mRNA hybridization in the kidney samples was about $25 \%$ compared with liver RNA. C4-specific transcripts were not present in isolated glomeruli but in the renal interstitium. Other human tissues, such as tonsil, spleen, thymus, brain, lung and peripheral mononuclear cells, contained no C4 mRNA. Low amounts of C4 mRNA were found in colon, thyroid gland, lymph node and breast carcinoma. The results obtained with lung, where C2 mRNA was found but no C4 mRNA, further indicate an independent, tissue-specific regulation of the class III gene expression. The results, showing that the complement $\mathrm{C} 4$ genes are transcribed very efficiently in normal human kidney, suggest a direct role of complement $\mathrm{C} 4$ in renal pathogenesis.
\end{abstract}

\section{Introduction}

The complement components $\mathrm{C} 4$, factor $\mathrm{B}$ and $\mathrm{C} 2$ are encoded on chromosome 6 between the class I and class II genes of the major histocompatibility complex (MHC) [1]. Recent studies have established the associations between alleles of the MHC-linked complement genes and various autoimmune diseases [2]. The fourth component of human complement is controlled by two highly polymorphic genes, C4A and C4B [3], and several forms of primary glomerulonephritis were found in association with certain alleles of $\mathrm{C} 4$ or with partial deficiency of $\mathrm{C} 4$ $[4,5]$. This peculiar disease association raised the question, of whether the structural variants of $\mathrm{C} 4$ might be directly involved in the pathogenesis of renal autoimmune diseases. Using an immunoperoxidase staining technique and monoclonal antibodies against $\mathrm{C} 4$, we have recently demonstrated the presence of both isotypic components $\mathrm{C} 4 \mathrm{~A}$ and $\mathrm{C} 4 \mathrm{~B}$ in glomeruli of normal human kidney [6]. The question however remained of whether complement $\mathrm{C} 4$ is passively adsorbed, or locally produced in human kidney.
Complement components in the serum are primarily produced in the liver [7]. However, extrahepatic production has also been noted. Already in 1965, using radiolabeled amino acids and immune electrophoresis of tissue culture supernatants, Thorbecke et al. [8] have provided evidence that several normal tissues produce complement $\mathrm{C} 3$ and to a less extent complement $\mathrm{C} 4$. In rhesus monkeys e.g. $\mathrm{C} 4$ production was also found in normal lung, mammary gland, thyroid gland and kidney. Investigating adult human tissues, thyroidea, breast and lung were found to produce complement $\mathrm{C} 4$ in addition to liver $[9,10]$. In these studies mononuclear phagocytes were identified as complement source, thus explaining also the local synthesis of complement components in inflamed tissues such as rheumatoid synovium [11]. The available complementary DNA (cDNA) probes specific for the MHC class III proteins C4, factor B and C2 [12-14] enabled us to readdress the question of biosynthesis of these components by Northern blot hybridization. Here we report that normal human kidney contains $\mathrm{C} 4$ messenger RNA (mRNA) in comparable amounts to human liver. 
Fig. 1. Presence of $\mathrm{C} 4 \mathrm{mRNA}$ in human kidney and liver. Northern blot analysis of 10 ug of total RNA prepared from various human organs (except kidney II*, where $7 \mu \mathrm{g}$ were applied) and hybridization with $\mathrm{C} 4 \mathrm{~d}$-specific cDNA probe Alu-7 (a). b Total RNA from mouse liver is included. $\mathrm{PBMNC}=$ Peripheral blood mononuclear cells. $28 \mathrm{~s}$ and 18 s represent the large and small subunit of ribosomal RNA. Different numbers refer to different patients.

\section{Methods}

\section{Tissue Samples}

Human tissue specimens obtained during surgery were immediately snap frozen in liquid nitrogen and transferred to the laboratory for further processing.

Kidney tissue was obtained from 5 patients (ranging in age from 44 to 71 years) undergoing nephrectomy due to renal carcinoma. Only histologically normal, tumor-free sections, as judged by light microscopy were used for preparation of total RNA. One sample was also obtained from renal carcinoma. Whole glomeruli were isolated from renal cortex cut into small pieces. Tubular and fibrous material was removed by subsequent sieving through nylon meshes of different pore size ( 500 and $250 \mu \mathrm{m}$, respectively). Glomeruli were retained on and rinsed from a mesh with $125 \mu \mathrm{m}$ opening size. Ice-cold media were used throughout. Tonsils were obtained from children with adenoid hyperplasia, thymus was obtained during open heart surgery. Thyroid gland was removed either totally because of carcinoma or partially due to toxic adenoma. Spleens were taken from patients after trauma. Histologically normal colon was taken from colectomies due to carcinoma. During removal of carcinoma, normal tissue specimens were obtained from lung, liver, lymph nodes, and also two samples from breast carcinoma. Peripheral blood mononuclear cells were isolated by density gradient centrifugation. Brain was obtained at autopsy.

Preparation of Total RNA and Hybridization with $C D N A$ Probes

Total RNA was prepared from each tissue sample by standard procedures [15]. Ten micrograms of total RNA were separated on a formamide agarose gel and transferred to nylon membranes. cDNA probes were labeled with ${ }^{32} \mathrm{P}$ according to the method of Feinberg and Vogelstein [16]. The Northern blots were hybridized overnight at $65^{\circ} \mathrm{C}$ with labeled cDNA probes at an activity of $2-5 \times 10^{6} \mathrm{cpm} / \mathrm{ml}$ in $3 \times$ saline sodium citrate buffer $(20 \times \mathrm{SSC}=3 \mathrm{M} \mathrm{NaCl}, 0.3 \mathrm{M}$ Na-citrate), $10 \times$ Denhardt's solution, $0.1 \%$ sodium dodecyl sulfate
(SDS), $0.1 \%$ sodium pyrophosphate, $10 \%$ dextran sulfate, $50 \mathrm{~g} / \mathrm{ml}$ denatured salmon sperm DNA. Washing was performed stepwise for $30 \mathrm{~min}$ at $65^{\circ} \mathrm{C}$ in buffers with decreasing SSC concentration, reaching $0.1 \% \mathrm{SSC}, 0.1 \% \mathrm{SDS}$ during the last step.

\section{C4, Factor B- and C2-Specific cDNA Probes}

Initially, Alu-7, a cDNA probe of 300 base pairs (BP) which is specific for the amino acid sequence of $\mathrm{C} 4 \mathrm{~d}$ of both $\mathrm{C} 4$ isotypes [12] was employed and later pAT-A, which contains the full-length 5.5-kb C4A transcript [17]. The $515 \mathrm{BP}$ cDNA probe $\mathrm{FBl}$ is specific for factor $\mathrm{B}$ [13] and the $900 \mathrm{BP}$ cDNA probe $\mathrm{pC} 2-6$ is specific for $\mathrm{C} 2$ [14].

Bacteria containing the relevant class III cDNA clones were kindly provided by Dr. M.C. Carroll (Oxford) and Dr. P. Schneider (Mainz). The plasmids were isolated from 11 overnight cultures by the alkaline lysis method [18] and purified on a cesium-chloride gradient. Fifty micrograms of the plasmids were digested with the appropriate restriction enzymes to cut out the cDNA insert, and separated on a preparative $0.7 \%$ agarose gel. The cDNA fragments were isolated from the gel by electroelution.

Slot blot hybridization, using decreasing amounts of total RNA, was done according to the method of Kafatos et al. [19]. Control hybridization was performed with a human actin-specific cDNA probe [20].

\section{Results}

\section{Detection of C4 $m R N A$ in Human Kidney}

Total RNA was prepared from five different kidney samples and was analyzed for the presence of C4 mRNA by Northern and slot blot hybridization with two $\mathrm{C} 4$ cDNA probes. Distinct hybridization with the C4d-spe- 


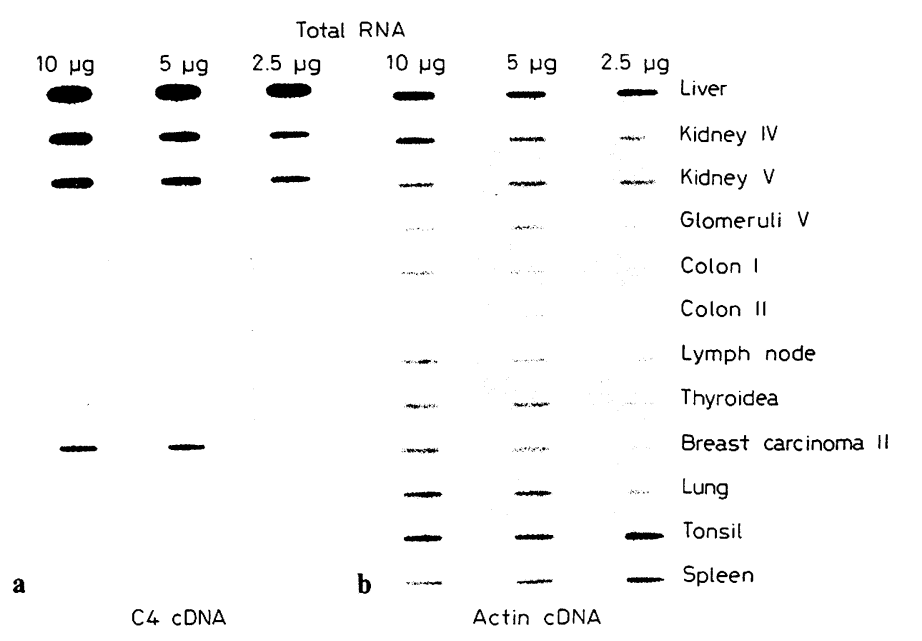

Fig. 2. Intensity of C4 mRNA biosynthesis in various human organs. Slot blot analysis of total RNA, hybridized with full length C 4 cDNA probe pAT-A. Kidney IV and V and colon I and II refer to different patients. Exposure was $24 \mathrm{~h}$. (a) Control hybridization with actin-specific cDNA probe (b) is shown.

cific cDNA probe Alu-7 and the full-length $\mathrm{C} 4 \mathrm{cDNA}$ probe pAT-A was obtained with each kidney sample. Figure 1 shows the comparative hybridization to RNA from various human organs, including liver, kidney, isolated glomeruli, thymus, tonsil, spleen, brain (fig. la), peripheral blood mononuclear cells, renal carcinoma, breast carcinoma and mouse liver (fig. 1b). The C4 cDNA probe hybridizes to RNA of approximately $5.5 \mathrm{~kb}$ length in the liver sample and also to kidney RNA, thus demonstrating the presence of C4-specific transcripts in the different kidneys analyzed. Interestingly, only whole renal cortex contained C4 mRNA, whereas isolated glomeruli were consistently negative. No $\mathrm{C} 4$ transcripts were detected with RNA preparations from thymus, tonsil, spleen, brain, peripheral blood mononuclear cells, renal carcinoma, breast carcinoma and mouse liver.

In order to quantitate the amount of C4 mRNA, slot blot hybridization was performed, using decreasing amounts of total RNA (10,5 and $2.5 \mu \mathrm{g}$, respectively) per slot and the full length cDNA pAT-A as probe. A strong hybridization signal is displayed by liver RNA, whereas the intensity of C4 mRNA hybridization in two kidney samples is approximately $25 \%$ of the liver signal (fig. $2 a$ ). Again, no C4 mRNA is detected in isolated glomeruli. Very low amounts of C4 mRNA are found in RNA preparations from two colon samples, from lymph node and from thyroid gland. Weak hybridization is seen in the RNA isolated from breast carcinoma. Lung, tonsil and spleen are negative. In order to show that all RNA pre-

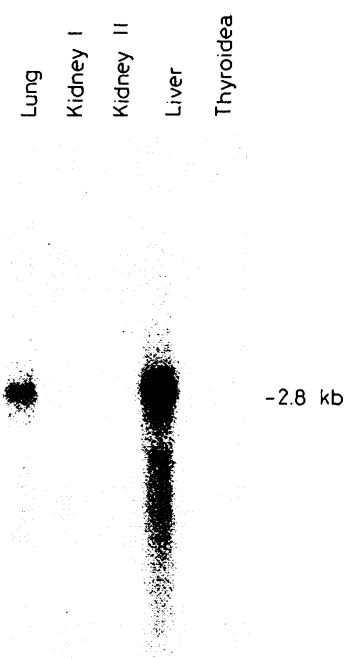

Fig. 3. Presence of $C 2$ mRNA in human liver and lung. Northern blot analysis of total RNA and hybridization with $\mathrm{C} 2$-specific cDNA probe $\mathrm{pC} 2-6$. Different numbers refer to different patients.

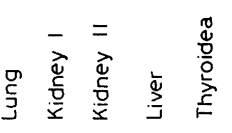

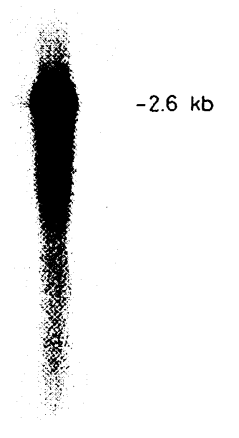

Fig. 4. Presence of factor B mRNA. Appearance of weak hybridization signals with cDNA probe $\mathrm{FBI}$ after prolonged exposure $(48 \mathrm{~h})$ in RNA preparations from lung, thyroid gland and two kidney samples. Different numbers refer to different patients.

parations used in this study were of equal quality and that roughly equal amounts of total RNA were tested, a control hybridization was performed with a human actinspecific probe. In all samples actin mRNA of $1.8 \mathrm{~kb}$ length is present and comparable signals are obtained in slot blot hybridization (fig. 2b). This result demonstrates that the failure to detect complement mRNA in the samples (e.g. in isolated glomeruli) is not due to degraded or too little RNA applied.

\section{Detection of $C 2 m R N A$ and Factor $B m R N A$ by Northern} Blot Analysis

It was then of interest to investigate whether normal human kidney would also transcribe the class III genes coding for complement components $\mathrm{C} 2$ and factor $\mathrm{B}$. For 
this purpose, the Northern blots were hybridized with the C2-specific cDNA probe $\mathrm{pC} 2-6$ and the factor B-specific probe $\mathrm{FB} 1$, respectively. As shown in figure 3, C2 transcripts of $2.8 \mathrm{~kb}$ length are present in liver and in lung, whereas two kidney samples and thyroid gland are negative. In contrast, only liver RNA hybridizes strongly with the factor B-specific cDNA probe, yielding a band at 2.6 $\mathrm{kb}$. After prolonged exposure, a weak signal is also observed in the lung and kidney RNA preparations (fig. 4).

\section{Discussion}

Hybridization techniques using cDNA probes have already allowed to demonstrate the renal production of proteins such as factor VIII, Tamm-Horsfall glycoprotein, $\alpha$-fetoprotein and albumin [21-23]. In this study we were interested in the extrahepatic production of the MHC-linked complement components. For this purpose, we investigated various human organs for the presence of $\mathrm{C} 4$, factor $\mathrm{B}$ and $\mathrm{C} 2 \mathrm{mRNA}$ by Northern blot and slot blot analyses. A high amount of C4 mRNA was found in liver, and surprisingly a signal of remarkable intensity appeared also in normal human kidney. Renal carcinoma was devoid of C4 mRNA. No C2 mRNA and only very low amounts of factor B mRNA could be detected in human kidney. The presence of C4 mRNA strongly suggests that the $\mathrm{C} 4$ protein is locally synthesized in the kidney. These results confirm the early observations by Thorbecke et al. [8] in rhesus monkeys. Biosynthesis of C4 mRNA does, however, not take place in glomeruli but in the interstitium, as no C4-specific transcripts were present in RNA extracted from isolated glomeruli.

Within the interstitium, the tubular system is the most likely source of complement production. Macrophages, as another possible source, can be excluded, since we (own observation) and others [24] could not identify interstitial macrophages in normal human kidney with immunohistological techniques and no C4 mRNA could be detected in organs known to contain numerous tissue macrophages such as tonsil, spleen and lung. When, however, murine lupus was investigated, the increased local production of complement proteins $\mathrm{C} 3$, factor $\mathrm{B}, \mathrm{C} 2$ and $\mathrm{C} 4$ was caused by macrophages infiltrating the diseased organs, primarily the kidneys [25]. Using an immunoperoxidase staining technique and several monoclonal antibodies against complement $\mathrm{C} 4$, we recently demonstrated the presence of $\mathrm{C} 4$ in all normal human glomeruli [6]. The question then arose of whether the glomeruli themselves would produce the detected $\mathrm{C} 4$.
The present study shows that the glomeruli do not transcribe the $\mathrm{C} 4$ gene; the glomerular $\mathrm{C} 4$ protein is therefore a deposit which is passively absorbed. It should also be noted that although the renal interstitium is the obvious site of $\mathrm{C} 4$ production, immunoperoxidase staining with monoclonal anti-C4 reagents was consistently negative [6]. This finding is in agreement with the results obtained with sections from human liver. Despite the $\mathrm{C} 4$ production by hepatocytes, as confirmed by the presence of $C 4$ mRNA, we could not detect $\mathrm{C} 4$ protein in liver tissue by immunoperoxidase staining. And to our knowledge the immunohistological presence of $\mathrm{C} 4$ in human liver has not been reported so far.

When additional normal human tissues were investigated for the presence of C4 mRNA, brain and thymus were completely negative, whereas lymph node, colon and thyroid gland contained a low amount of C4 mRNA. The results obtained with lung, where $\mathrm{C} 2$ mRNA was found but no $\mathrm{C} 4 \mathrm{mRNA}$, indicate an independent, tissuespecific regulation of the class III gene expression.

Similar to human liver, where a genetically determined low production of $\mathrm{C} 4$ is predisposing to the development of autoimmune chronic active hepatitis [26], the local presence and autochthonous production of $\mathrm{C} 4$ might be of relevance also for the pathogenesis of renal diseases. The classical pathway of complement activation, involving the components $\mathrm{C} 1, \mathrm{C} 4$ and $\mathrm{C} 2$, resulting in the formation of the C3-convertase, is a powerful mechanism for the elimination of immune complexes [27]. It is therefore important to determine, whether the 'renal complement' enters the circulation and whether it is protective against the accumulation and deposition of immune complexes in the kidney.

With respect to the putative tubular production of $\mathrm{C} 4$, there is also the possibility of excretion into the tubular lumen and finally into urine. In vitro experiments have already shown production of $\mathrm{Cl}$ components by epithelial cells from the urogenital tract including renal pelvis [28]. We have therefore examined normal urine specimens for the presence of $\mathrm{C} 4$ by protein precipitation followed by immunoblotting and $\mathrm{C} 4$ protein could be clearly detected [data not shown]. With this approach, it is impossible, however, to determine, whether the $\mathrm{C} 4$ protein, although having a molecular weight of 200,000 daltons is derived from glomerular filtration, from actual tubular secretion or from both. With regard to the antibacterial and antiviral action of complement [29], another important task could therefore be the participation in the local protection against interstitial or ascending renal infection. 
In conclusion, the results showing a very efficient transcription of the complement $\mathrm{C} 4$ genes in normal human kidney suggest a direct role of complement $\mathrm{C} 4$ in renal pathogenesis.

\section{Acknowledgments}

We thank Dr. G.J. O'Neill (Miami, Fla.) for continuous help and advice. Intraoperative kidney specimens were provided by Dr. M. Prosinger and Dr. R. Tauber (München). This work was supported by grants from the Deutsche Forschungsgemeinschaft, SFB 217: C8 (H.F.) and from the Genzentrum München (E.W.).

\section{References}

1 Carroll MC, Campbell RD, Bentley DR, et al: A molecular map of the human major histocompatibility complex class III region linking complement genes C4, C2 and factor B. Nature 1984; 307:237-241.

2 Rittner C, Bertrams J: The significance of C2, C4 and factor B polymorphism in disease. Hum Genet 1982;56:235-247.

3 O'Neill GJ, Yang SJ, Dupont B: Two HLA-linked loci controlling the fourth component of human complement. Proc Natl Acad Sci USA 1978;75:5154-5169.

4 Wank R, Schendel DJ, O'Neill GJ, et al: Rare variant of complement $\mathrm{C} 4$ is seen in high frequency in patients with primary glomerulonephritis. Lancet 1984; i:872-874.

5 Welch TR, Beischel L, Balakrishnan K, et al: Major-histocompatibility-complex extended haplotypes in membranoproliferative glomerulonephritis. N Engl J Med 1986;314:1476-1481.

6 Feucht HE, Jung C-M, Gokel MJ, et al: Detection of both isotypes of complement $\mathrm{C} 4, \mathrm{C} 4 \mathrm{~A}$ and $\mathrm{C} 4 \mathrm{~B}$, in normal human glomeruli. Kidney Int 1986;30:932-936.

7 Fey G, Colten HR: Biosynthesis of complement components. Fed Proc 1981;40:2099-2104.

8 Thorbecke GJ, Hochwald GM, van Furth R, et al: Problems in determining the sites of synthesis of complement components; in Wolstenholme GEW, Knight J (eds): Ciba Symposium 'Complement' London, Churchill, 1965, pp 99-119.

9 Cole FS, Schneeberger EE, Lichtenberg NA, et al: Complement biosynthesis in human breast milk macrophages and blood monocytes. Immunology 1982;46:429-441.

10 Cole FS, Matthews WJ, Rossing TH, et al: Complement biosynthesis by human bronchoalveolar macrophages. Clin Immunol Immunopathol 1983;27:153-158.

11 Ruddy S, Colten HR: Rheumatoid arthritis: Biosynthesis of complement proteins by synovial tissues. N Engl J Med 1974; 290:1284-1288.

12 Carroll MC, Porter RR: Cloning of a human complement C4 gene. Proc Natl Acad Sci USA 1983;80:264-267.

13 Campbell RD, Porter RR: Molecular cloning and characterization of the gene coding for human complement protein factor $\mathrm{B}$. Proc Natl Acad Sci USA 1983;80:4464-4468.

14 Woods DE, Edge MD, Colten HR: Isolation of a complementary DNA clone for the human complement protein $\mathrm{C} 2$ and its use in the identification of a restriction fragment length polymorphism. J Clin Invest 1984;74:634-638.

15 Chirgwin JM, Przybyla AE, Mac Donald RJ, et al: Isolation of biologically active ribonucleic acid from sources enriched in ribonuclease. Biochemistry 1979;18:5294-5299.

16 Feinberg AP, Vogelstein B: A technique for radiolabeling DNA restriction endonuclease fragments to high specific activity. Anal Biochem 1984;137:266-267.

17 Belt KT, Carroll MC, Porter RR: The structural basis of the multiple forms of human complement component $\mathrm{C} 4$. Cell 1984;36:907-914.

18 Birnboim HC: A rapid alkaline extraction method for the isolation of plasmid DNA. Methods Enzymol 1983;100:243-255.

19 Kafatos FC, Jones WC, Efstratiadis A: Determination of nucleic acid sequence homologies and relative concentrations by a dot hybridization procedure. Nucleic Acids Res 1979; 7:1541-1552.

20 Weiss EH, Cheah KSE, Grosveld FG, et al: Isolation and characterization of a human collagen 1 (I)-like gene from a cosmid library. Nucleic Acids Res 1982;10:1981-1994.

21 Nahon J-L, Gal A, Erdos T, et al: Differential DNase I sensitivity of the albumin and $\alpha$-fetoprotein genes in chromatin from rat tissue and cell lines. Proc Natl Acad Sci USA 1984;81: 5031-5035.

22 Pennica D, Kohr WJ, Kuang W-J, et al: Identification of human uromodulin as the Tamm-Horsfall urinary glycoprotein. Science 1987;236:83-88.

23 Wion KL, Kelly D, Summerfield JA, et al: Distribution of factor VIII mRNA and antigen in human liver and other tissues. Nature 1985;317:726-729.

24 Boucher A, Droz D, Adafer E, et al: Characterization of mononuclear cell subsets in renal cellular interstitial infiltrates. Kidney Int 1986;29:1043-1049.

25 Passwell J, Schreiner GF, Nonaka M, et al: Local extrahepatic expression of complement genes $\mathrm{C} 3$, factor $\mathrm{B}, \mathrm{C} 2$ and $\mathrm{C} 4$ is increased in murine lupus nephritis. J Clin Invest 1988:82: 1676-1684.

26 Vergani D, Wells L, Larcher VF, et al: Genetically determined low C4: A predisposing factor to autoimmune chronic active hepatitis. Lancet 1985 ; ii:294-298.

27 Schifferli JA, Ng YC, Peters DK: The role of complement and its receptor in the elimination of immune complexes. N Engl J Med $1986 ; 315: 488-495$.

28 Morris KM, Colten HR, Bing DH: The first component of complement. A quantitative comparison of its biosynthesis in culture by human epithelial and mesenchymal cells. J Exp Med 1978;148:1007-1019.

29 Joiner KA, Frank MM: Molecular mechanisms in the antibacterial action of complement; in Cinader B, Miller RG (eds): Progress in Immunology. Part VI. Orlando, Academic Press, 1986, pp 282-290.

Accepted: March 17, 1989

Dr. Helmut E. Feucht

Medizinische Klinik Innenstadt

Universität München

Ziemssenstrasse 1

D-8000 München 2 (FRG) 